\title{
$\begin{array}{ll}\text { Research Square } & \text { Preprints are preliminary reports that have not undergone peer review. } \\ \text { They should not be considered conclusive, used to inform clinical practice, }\end{array}$ or referenced by the media as validated information. \\ Does Exchange Rate Impact Commodity Prices: Evidence From a Small Open Economy
}

Kore Marc Antoine Guei ( $\nabla$ marcgueik@gmail.com )

TRADE research entity, Faculty of Economic and Management Sciences (F-EMS), North-West University (NWU), South Africa.

\section{IREEN CHOGA}

Associate Professor: Economics North West University Mafikeng Campus Private Bag X2046, Mmabatho, 2735

\section{Research}

Keywords: Commodity prices, exchange rate, real interest rate

Posted Date: February 10th, 2021

DOl: https://doi.org/10.21203/rs.3.rs-215311/v1

License: (9) This work is licensed under a Creative Commons Attribution 4.0 International License. Read Full License 


\title{
Does exchange rate impact commodity prices: Evidence from a small open economy
}

\begin{abstract}
:
The paper assesses the dynamics of exchange rate and the terms of trade on industrial commodity prices. We investigate the linear and asymmetric effects of exchange rate on commodity prices using an error correction model (ECM) and a threshold autoregressive (TAR) model that allows to estimate the dynamics of different regimes. Further we employ a structural vector autoregressive (SVAR) model to examine the impact of an external shock on the terms of trade using quarterly data over the period $1992 q 1$ to $2019 q 4$.

The results suggest that an exchange rate above or equal 4.6 has a positive and significant impact on commodity prices. Specifically, if real exchange rate is above the threshold 4.6, the price of gold, copper, and nickel increases by $0.9 \%, 1.1 \%$, and $2.7 \%$, respectively. We also find that a $1 \%$ increase in real interest rate is associated with a $0.003 \%$ fall in the terms of trade.
\end{abstract}

Keywords: Commodity prices, exchange rate, real interest rate

JEL classification: E31, E43, F3 


\section{Introduction}

The fear that low interest rate in major industrialized nations contribute to macroeconomic volatility has aroused the interests of economists. This is because several developing and emerging economies are commodity exporting countries which are characterized by volatile business cycles. Several researchers have attempted to determine the link between gold prices and exchange rate (Pukthuanthong \& Rol 2011; Pierdzioch, Risse \& Rohloff, 2016). Others, on the other hand have focused on the relationship between agricultural prices and exchange rate (Nazlioglu \& Soytas, 2012; Campos, 2020).

The global economic slowdown has led several central banks (the Fed, ECB) to reduce interest rates (Gauti \& Summers, 2019). Frankel (2008) documents that real interest rate is an important determinant of commodity prices. He shows that a $1 \%$ increase in real interest rate is accompanied by a $5 \%$ decrease in commodity prices. Thus, commodity prices increase as long as monetary policies remain accommodative. This theory is supported by the exchange rate overshooting hypothesis (see Dornbusch, 1976). Another strand of research finds that real interest rate, fundamental factors, non-fundamental factors have significant influence on commodity prices (Scrimgeour, 2010; Frankel, 2014; Tadesse, Algieri, Kalkuhl, \& Von Braun, 2014).

We contribute to the literature in the following way: Recent research have focused on agricultural commodity prices (wheat, corn, soybean) from the US perspective (Campos, 2019), we extend the research by examining the industrial commodity (gold, copper, nickel) fluctuations using data from South Africa. Secondly, he treats agricultural commodities as a panel data and employ the Hansen threshold panel model. In this study, the data are treated as time series data which allows to examine the effects of each commodity price separately. Thirdly our econometric specification model departs from the literature because we employ a linear regression model and an asymmetric regression model to examine the effects of exchange rate on commodity prices. One of our most notable contribution is that we use a restricted VAR model to determine how the terms of trade responds to an external negative shock.

We consider South Africa to be a small open economy and we follow the work of Frankel (2008, 2014) who relies on fundamental condition to predict the changes of gold price. To the best of our knowledge, empirical studies have not yet examined the threshold effect of exchange rate on industrial commodity prices. The study therefore attempts to fill this gap. Figure 1 shows the commodity price movements and exchange rate during the period 2000q1-2019q4. 


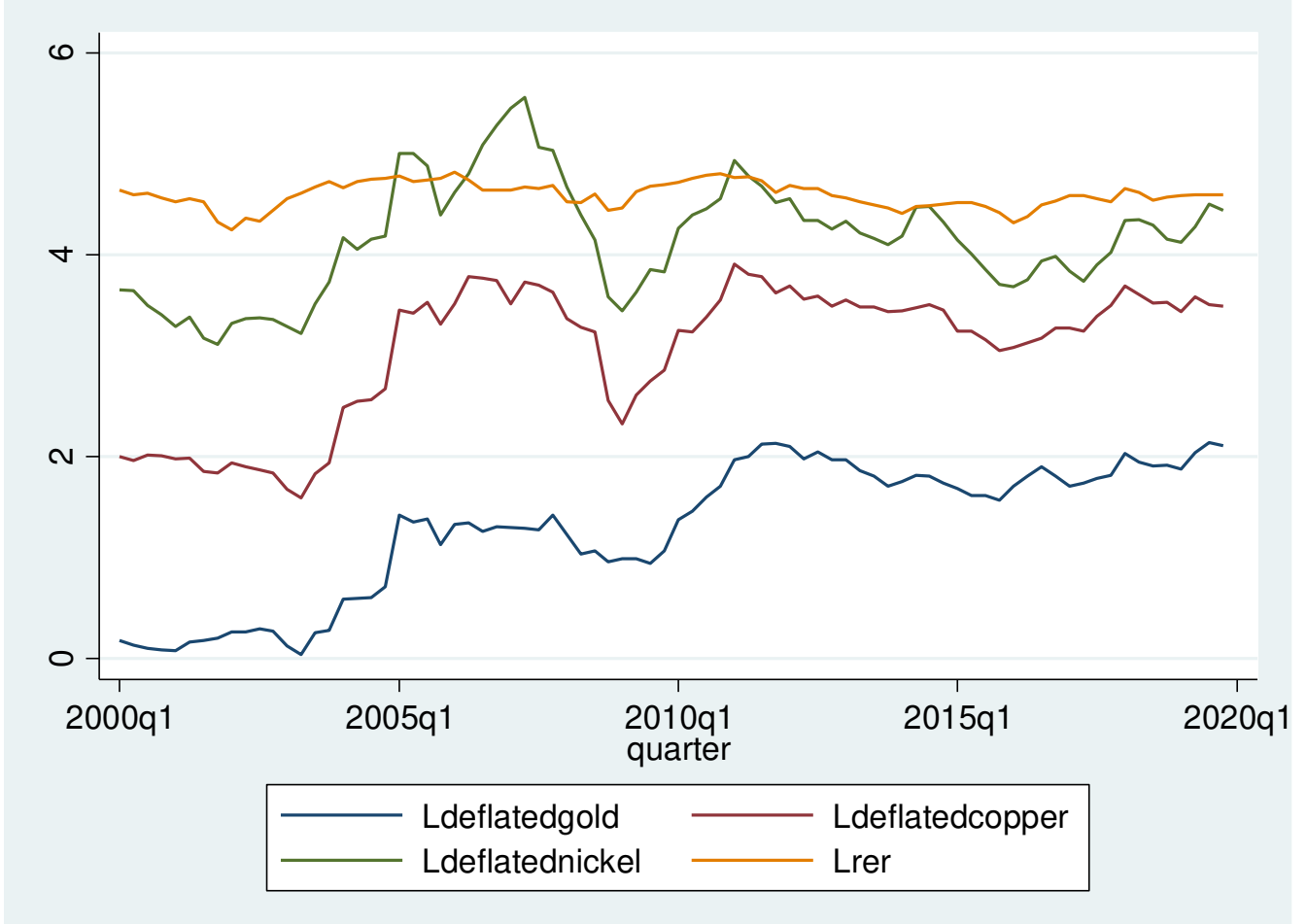

Fig.1: Deflated industrial commodity prices vs real exchange rate from 2000q1 to 2019q4. Source: Author's estimation

Contrary to Campos (2019) who uses a fixed panel threshold effect because the time series are stationary, we initially present the results of an error correction model because our series are not stationary in levels. There seems to be a strong evidence of asymmetric relation (see Fig.1), hence we estimate the TAR model. The non-linear adjustment process is obtained through the threshold corresponding to the proportional transaction costs (Obstfeld and Taylor, 1997). One possible explanation can be related to the global financial crisis. We propose this methodology because it helps improve the literature in several ways: (i) It is up to the researcher to select the variables that determine the regime; (ii) The regime is not imposed by the researcher, rather it is determined by the chosen variable relative to the threshold. This restriction is important when we are dealing with a sample containing structural breaks.

The remainder of the paper is structured as follows: the following section presents the data used. Section 3 discusses the econometric method and shows the results. Section 4 concludes.

\section{Literature review}

The early work of Meese \& Rogoff (1983) find that monetary fundamentals largely impact exchange rate. Since then, many related studies have shown that monetary fundamentals, agricultural commodities and energy commodities play an important role in understanding exchange rate variations in export-oriented economy (Rossi, 2013; Pierdzioch, Risse, \& Rohloff, 2016). Rossi (2013) document that commodity prices can be used to forecast exchange rate. 
Frankel \& Rose (2010) employ a set of fundamental no-arbitrage conditions to assess the dynamics of gold price in a small open economy. They show that gold price can be modelled as a linear combination of a large country real interest rate and movements of the real exchange rate. This result is documented by Frankel (2014) who point out that real interest rate has a significant explanatory role in predicting various commodity prices.

Also oil price is considered to play an important role in determining the fluctuations of commodity prices. A large body of literature related to oil and the dynamics of commodity prices is available. Hamilton (2008) investigates the determinants of crude oil prices by reviewing the features of petroleum supply and demand. He shows that OPEC monopoly pricing, production and commodity price speculations are important determinant of the scarcity rent. Salisu \& Mobolaji (2013) examines the volatility transmission between oil price and exchange rate using a VARGARCH model that allows for structural breaks. Their findings reveal a bi-directional spillover transmission between foreign exchange and oil.

Recent studies have shown that commodity prices contribute to a large extent to the change in macroeconomic indicators such as GDP and inflation (Lof \& Nyberg, 2017). Using a battery of new macroeconometric models, Mallick \& Sousa (2013) highlight the role of commodity prices which help explain the inflation patterns.

The evidence that the trade balance is sensitive to changes in the exchange rate is well documented (Musa, 1982, Ahumada \& Cornejo, 2015). Beckman \& Czudaj (2013) show that the transmission mechanisms between the oil price and exchange rate are the terms of trade and the balance of payments.

Predictive models of commodity prices only hold for commodities that are actively traded such as energy and metals because of their sensitivity to macroeconomic factors.

Hence our study is motivated to understand the transmission channel of commodity prices on the South African economy by assessing the effects of foreign exchange on industrial commodity prices. We first conduct a cointegration test which has been widely used in the literature (see Ding \& Zhang, 2020) to examine the long linear relationship among the series. Secondly, we test the presence of an asymmetric relation in the model. Thirdly, we follow the work of (Beckman \& Czudaj, 2013; Ahumada \& Cornejo, 2015) and investigate how a negative external shock may affect the terms of trade.

\section{Data used}

We consider 3 major industrial traded commodities in this paper: precious metal (gold), and industrial metals (copper and nickel). First, we use new nominal price data of the three commodities obtained from Quantec Easy data. Second we compute the real price of each commodity by taking into account the inflation adjustment. For instance, the deflated price of gold is calculated by the following formula: [deflated price of gold $=\log$ (price of gold/CPI*100)]. The CPI stands for consumer price index for all items, seasonally adjusted. It is obtained from the Federal Reserve Bank of St-Louis.

Similar to Frankel (2014), we compute the real interest rate using the following formula: 
[RIR $\left.=\left(\mathrm{NR}_{\mathrm{q}} / 100-\mathrm{I}_{\mathrm{q}-1}\right) * 100\right]$, where RIR, NR, q, and I represent real interest rate, nominal rate, quarter, and inflation, respectively. We use the three-month treasury bill, not seasonally adjusted as in Frankel (2014) for nominal rate. This data is obtained from the FED database. We use the USA as the large country and we employ the US real interest rate as in Frankel $(1986,2008)$.

We control for fundamental and non-fundamental determinants of commodity prices by including additional variables such as real GDP, oil price, production, real exchange rate in South Africa.

We consider two sub-periods in our empirical analysis: the period (2000q1-2019q2) that we use to investigate the linear and asymmetric effect of exchange rate on commodity prices and the period (1992q1-2019q2) in which we estimate a system of exchange rate, commodity price index, real interest rate, terms of trade, and real GDP to determine the responsiveness of the terms of trade in the presence of an external shock. All the variables are converted into natural logs. A full definition of the variables used is provided in the appendix section.

\section{Econometric framework and Results}

We perform a stationarity test using the augmented dicker fuller (ADF) test. The results are reported in Table 1. The variables are stationary in their first difference. We then perform a cointegration test using two tests, the Engle and Granger (EG, 1987) two step method and the trace and maximum eigen value. The results from the ADF test suggest that we can reject the null hypothesis of no cointegration at $1 \%$ level. For the EG test, we allow the t-significance and the AIC to determine the lag order.

Table 1: Unit root test

\begin{tabular}{|c|c|c|c|c|}
\hline \multirow[t]{2}{*}{ Variables } & \multicolumn{2}{|c|}{ Model specification } & \multirow[t]{2}{*}{ T-statistics } & \multirow{2}{*}{$\begin{array}{l}\text { Unit root test status ( } 1 \% \\
\text { level) }\end{array}$} \\
\hline & Without trend & With trend & & \\
\hline \multicolumn{5}{|l|}{ ADF } \\
\hline \multicolumn{5}{|c|}{ Commodities } \\
\hline Gold & $\begin{array}{l}-0.811^{* * *} \\
(0.154)\end{array}$ & $\begin{array}{l}-0.877^{* * *} \\
(0.160)\end{array}$ & -5.476 & No \\
\hline Copper & $\begin{array}{l}-0.786^{* * *} \\
(0.149)\end{array}$ & $\begin{array}{l}-0.810^{* * *} \\
(0.153)\end{array}$ & -5.288 & No \\
\hline Nickel & $\begin{array}{l}-0.693^{* * *} \\
(0.140)\end{array}$ & $\begin{array}{l}-0.698^{* * *} \\
(0.142)\end{array}$ & -4.901 & No \\
\hline \multicolumn{5}{|c|}{ Macroeconomic variables } \\
\hline Rer & $\begin{array}{l}-1.056^{* * *} \\
(0.154)\end{array}$ & $\begin{array}{l}-1.057^{* * *} \\
(0.156)\end{array}$ & -6.737 & No \\
\hline Oil & $\begin{array}{l}-0.982^{* * *} \\
(0.143)\end{array}$ & $\begin{array}{l}-1.003^{* * *} \\
(0.146)\end{array}$ & -6.838 & No \\
\hline Rgdp & $\begin{array}{l}-0.125^{* * *} \\
(0.065)\end{array}$ & $\begin{array}{l}-1.090^{* * *} \\
(0.168)\end{array}$ & -6.456 & No \\
\hline Invt & $\begin{array}{l}-1.597^{* * *} \\
(0.232)\end{array}$ & $\begin{array}{l}-1.642^{* * *} \\
(0.245) \\
\end{array}$ & -6.698 & No \\
\hline Progold & $\begin{array}{l}-1.922^{* * *} \\
(0.162)\end{array}$ & $\begin{array}{l}-1.922^{* * *} \\
(0.165)\end{array}$ & -11.645 & No \\
\hline
\end{tabular}




\begin{tabular}{|l|l|l|l|l|}
\hline Procopper & $-1.521^{* * *}$ & $-1.548^{* * *}$ & -8.531 & No \\
& $(0.179)$ & $(0.181)$ & & \\
\hline Pronickel & $-1.763^{* * *}$ & $-1.771^{* * *}$ & -9.092 & No \\
& $(0.192)$ & $(0.194)$ & & \\
\hline Rir & $-0.721^{* * *}$ & $-0.764^{* * *}$ & -5.274 & No \\
& $(0.140)$ & $(0.144)$ & & \\
\hline
\end{tabular}

Note: Critical values for the ADF with a trend are: -4.091 and -3.473 at the $1 \%$ and $5 \%$ levels, respectively. Critical values for the ADF without a trend are: -2.644 and -1.950 at the $1 \%$ and $5 \%$ levels, respectively. we report the results of the T-statistics with a trend after differencing all the variables. All the series are stationary using the Akaike information criteria at lag1.

The results from the EG test suggest that we can reject the null hypothesis of no cointegration at the 5\% level, hence we can conclude that our series are cointegrated. Table 2 shows the results of the EG test while Table 3 displays the trace and maximum eigen test. Table 3 supports the findings of EG that indeed the series are cointegrated. Both tests indicate a plausible existence of a long run relationship among the series.

Table 2: EG Two-step Method

Table 2.a: Cointegration test (Dependent variable Lgold)

\begin{tabular}{|l|l|l|l|l|}
\hline & Test statistics & Critical values \\
\hline & & 0.01 & 0.05 & 0.10 \\
\hline $\mathrm{Z}(\mathrm{t})$ & -3.677 & -4.088 & -3.472 & -3.163 \\
\hline
\end{tabular}

Note: Mackinnon approximate $\mathrm{p}$-value for $\mathrm{Z}(\mathrm{t})=0.0239$

Table 2.b: Cointegration test (Dependent variable Lcopper)

\begin{tabular}{|l|l|l|l|l|}
\hline & Test statistics & Critical values & \multicolumn{3}{l|}{} \\
\hline & & 0.01 & 0.05 & 0.10 \\
\hline $\mathrm{Z}(\mathrm{t})$ & -3.677 & -4.088 & -3.472 & -3.163 \\
\hline
\end{tabular}

Note: Mackinnon approximate $\mathrm{p}$-value for $\mathrm{Z}(\mathrm{t})=0.0325$

Table 2.b: Cointegration test (Dependent variable Lnickel)

\begin{tabular}{|l|l|l|l|l|}
\hline & Test statistics & Critical values & \\
\hline & & 0.01 & 0.05 & 0.10 \\
\hline $\mathrm{Z}(\mathrm{t})$ & -3.990 & -4.086 & -3.471 & -3.163 \\
\hline
\end{tabular}

Note: Mackinnon approximate $\mathrm{p}$-value for $\mathrm{Z}(\mathrm{t})=0.0091$

Table 3: Trace test and maximum eigen test

Table 3a: (Dependent variable Lgold)

\begin{tabular}{|l|l|l|l|l|l|}
\hline $\begin{array}{l}\text { Hypothesized no. } \\
\text { of CE (s) }\end{array}$ & \multicolumn{4}{|l|}{ Trace } & \multicolumn{2}{l|}{ Max eigen } \\
\hline & Eigen values & Statistics & $\begin{array}{l}0.05 \text { critical } \\
\text { value }\end{array}$ & Statistics & $\begin{array}{l}0.05 \text { critical } \\
\text { value }\end{array}$ \\
\hline
\end{tabular}




\begin{tabular}{|l|l|l|l|l|l|}
\hline None & - & 132.666 & 104.94 & 50.330 & 42.48 \\
\hline At most 1 & 0.475 & 82.335 & 77.74 & 37.496 & 36.41 \\
\hline At most 2 & 0.381 & 44.838 & 54.64 & 24.311 & 30.33 \\
\hline At most 3 & 0.267 & 20.527 & 34.55 & 11.807 & 23.78 \\
\hline
\end{tabular}

Note: Max-eigenvalue test indicates 3 cointegrating equations at $5 \%$ level.

Table 3b: (Dependent variable Lcopper)

\begin{tabular}{|l|l|l|l|l|l|}
\hline $\begin{array}{l}\text { Hypothesized no. of } \\
\text { CE }(\mathrm{s})\end{array}$ & \multicolumn{2}{l|}{ Trace } & \multicolumn{2}{l|}{ Max eigen } \\
\hline & Eigen values & Statistics & $\begin{array}{l}0.05 \text { critical } \\
\text { value }\end{array}$ & Statistics & $\begin{array}{l}0.05 \text { critical } \\
\text { value }\end{array}$ \\
\hline None & - & 126.915 & 104.94 & 46.496 & 42.48 \\
\hline At most 1 & 0.457 & 80.419 & 77.74 & 29.130 & 36.41 \\
\hline At most 2 & 0.318 & 51.288 & 54.64 & 27.681 & 30.33 \\
\hline At most 3 & 0.305 & 23.607 & 34.55 & 13.073 & 23.78 \\
\hline
\end{tabular}

Note: Max-eigenvalue test indicates 3 cointegrating equations at $5 \%$ level.

Table 3c: (Dependent variable Lnickel)

\begin{tabular}{|l|l|l|l|l|l|}
\hline $\begin{array}{l}\text { Hypothesized no. of } \\
\text { CE }(\mathrm{s})\end{array}$ & \multicolumn{2}{|l|}{ Trace } & \multicolumn{2}{l|}{ Max eigen } \\
\hline & Eigen values & Statistics & $\begin{array}{l}0.05 \text { critical } \\
\text { value }\end{array}$ & Statistics & $\begin{array}{l}0.05 \text { critical } \\
\text { value }\end{array}$ \\
\hline None & - & 115.825 & 104.94 & 45.692 & 42.48 \\
\hline At most 1 & 0.443 & 70.132 & 77.74 & 27.206 & 36.41 \\
\hline At most 2 & 0.294 & 42.926 & 56.64 & 21.848 & 30.33 \\
\hline At most 3 & 0.244 & 21.078 & 34.55 & 13.331 & 23.78 \\
\hline
\end{tabular}

Note: Max-eigenvalue test indicates 3 cointegrating equations at $5 \%$ level.

We first present the results of an error correction model. The model allows to estimate the long run effect on gold, copper, and nickel. The cointegration and unit root test justify the use of this model. Following Pesaran, Shin, \& Smith, (2001), we estimate the long run relationship between the variables:

$\Delta \mathrm{y}_{\mathrm{t}}=\mathrm{b}_{0}+\mathrm{b}_{1} \mathrm{t}-\alpha\left(\mathrm{y}_{\mathrm{t}-\mathrm{i}}-\theta \mathrm{x}_{\mathrm{t}-\mathrm{i}}\right)+\sum_{i=1}^{P-1} \varphi \mathrm{yi} \Delta \mathrm{y}_{\mathrm{t}-\mathrm{i}}+\omega \Delta \mathrm{x}_{\mathrm{t}}+\sum_{i=1}^{q-1} \omega \mathrm{x}_{\mathrm{i}} \Delta \mathrm{x}_{\mathrm{t}-\mathrm{i}}+\mathrm{u}_{\mathrm{t}}$

Where $\alpha$ represents the speed of adjustment, $\omega$ are the short run coefficients and $\theta$ are the long run coefficients.

Table 4 suggests that a $1 \%$ increase in exchange rate causes the price of gold to increase by $2.8 \%$. On the other hand, a similar rise in exchange rate has no significant impact on the price of copper and gold in the long run. Another important finding is the coefficients of our non-fundamental determinant (production) which is negative and significant in all our specifications. It shows that a $1 \%$ increase in production of gold, copper, and nickel approximately reduces their price by $15 \%$, $12 \%$, and $10 \%$, respectively. This is an interesting finding for policy analysis because it suggests that production and prices of industrial commodity are inversely related. The practical implication is that policy makers can target quantities produced to alter the price of industrial commodities. 
Next, we examine the residuals of equation (1) with the TAR model. This is an alternative specification of our initial model and can be expressed as:

$\Delta \mathrm{u}_{\mathrm{t}}=\left\{\begin{array}{c}\rho 1 u t-1+\epsilon t \text { if } U t-1 \geq 0 \\ \rho 2 u t-1+\epsilon t \text { if } U t-1<0\end{array}\right.$

Where $\rho_{1}$ and $\rho_{2}$ are the speed adjustment coefficients.

The presence of non-linear adjustment mechanisms is found in (Enders \& Siklos, 2001). The model allows for the analysis of asymmetric time series in a multivariate context.

Table 4: error correction model

\begin{tabular}{|l|l|l|l|}
\hline & $\begin{array}{l}\text { Dependent variable } \\
\text { Lgold }\end{array}$ & $\begin{array}{l}\text { Dependent variable } \\
\text { Lcopper }\end{array}$ & $\begin{array}{l}\text { Dependent variable } \\
\text { Lnickel }\end{array}$ \\
\hline Variables & & & \\
\hline $\begin{array}{l}\text { Ldefl } \\
\text { Lrer }\end{array}$ & 1 & 1 & 1 \\
\hline Loil & $2.814^{* * *}$ & 0.698 & 0.579 \\
& $(1.044)$ & $(0.690)$ & $(0.515)$ \\
\hline Lrgdp & $-1.546^{* * *}$ & $-1.180^{* * *}$ & $-1.286^{* * *}$ \\
& $(0.427)$ & $(0.282)$ & $(0.215)$ \\
\hline Lprod & $5.419^{* * *}$ & 2.227 & 1.908 \\
& $(2.754)$ & $(1.833)$ & $(1.417)$ \\
\hline Lrir & $-15.831^{* * *}$ & $-12.090^{* * *}$ & $-10.909 * * *$ \\
& $(2.085)$ & $(1.386)$ & $(1.068)$ \\
\hline Trend & $0.201^{* * *}$ & $0.086^{*}$ & 0.007 \\
& $(0.075)$ & $(0.051)$ & $(0.038)$ \\
\hline Cons & -1.145 & -0.074 & -0.044 \\
\hline
\end{tabular}

Notes: Numbers in parentheses are estimated standard errors. * Significant at $10 \%$ level. ** Significant at the $5 \%$ level. *** Significant at the $1 \%$ level. Ldeflatedpm corresponds to the deflated price of the commodity. Lprod corresponds to the production level of each commodity

The lag order is this model is obtained through the AIC or the t-significance test. The threshold test confirms that the point estimate $\left(\rho_{1}\right.$ and $\rho_{2}$ ) have the appropriate sign for convergence (see Table 5). The $\phi$-statistic for the null hypothesis $\left(\rho_{1=} \rho_{2}=0\right)$ indicates that Ho can be rejected.

The statistic $\phi$ is greater than the critical values in all our specification at the $5 \%$ level (Table 5). Hence we can conclude that there is evidence of asymmetric adjustment. Equation 2 becomes:

$\Delta \mathrm{U}_{\mathrm{t}}=\rho_{1} \mathrm{I}_{\mathrm{t}} \mathrm{U}_{\mathrm{t}-1}+\rho_{2}\left(1-\mathrm{I}_{\mathrm{t}}\right) \mathrm{U}_{\mathrm{t}-1}+\mathrm{U}_{\mathrm{t}}$

Where It is the indicator function which is defined as :

$\mathrm{I}_{\mathrm{t}}=\left\{\begin{array}{c}1 \text { if } U t-1 \geq \mathrm{T} \\ 0 \text { if } U t-1<\mathrm{T}\end{array}\right.$

Where $\mathrm{T}$ corresponds to the threshold value. 
Table 5: Threshold test

Table 5a: (Dependent variable Lgold)

\begin{tabular}{|l|l|l|l|l|}
\hline & & $\rho_{1}$ & $\rho_{2}$ & $\phi\left(\rho_{1=} \rho_{2}\right)$ \\
\hline & AIC & $-0.164(0.0869)$ & $-0.206(0.0868)$ & 4.466 \\
\hline TAR & T-sig & $-0.157(0.0906)$ & $-0.195(0.0912)$ & 3.470 \\
\hline
\end{tabular}

Note: the figures in parentheses are the standard errors. $\phi$ refers to the null hypothesis of testing $\rho_{1}$ $=\rho_{2}$. The critical values of $\phi$ are approximately equal to $14.64,11.79$ and 10.13 at the $1 \%, 5 \%$, and $10 \%$ level, respectively.

Table 5b: (Dependent variable Lcopper)

\begin{tabular}{|l|l|l|l|l|}
\hline & & $\rho_{1}$ & $\rho_{2}$ & $\phi\left(\rho_{1}=\rho_{2}\right)$ \\
\hline & AIC & $-0.516(0.172)$ & $-0.559(0.178)$ & 5.917 \\
\hline TAR & T-sig & $-0.422(0.142)$ & $-0.269(0.114)$ & 6.589 \\
\hline
\end{tabular}

Note: the figures in parentheses are the standard errors. $\phi$ refers to the null hypothesis of testing $\rho_{1}$ $=\rho_{2}$. The critical values of $\phi$ are approximately equal to $15.33,12.02$ and 10.39 at the $1 \%, 5 \%$, and $10 \%$ level, respectively.

Table 5c: (Dependent variable Lnickel)

\begin{tabular}{|l|l|l|l|l|}
\hline & & $\rho_{1}$ & $\rho_{2}$ & $\phi\left(\rho_{1}=\rho_{2}\right)$ \\
\hline & AIC & $-0.496(0.203)$ & $-0.724(0.273)$ & 3.833 \\
\hline TAR & T-sig & $-0.390(0.123)$ & $-0.493(0.148)$ & 8.750 \\
\hline
\end{tabular}

Note: the figures in parentheses are the standard errors. $\phi$ refers to the null hypothesis of testing $\rho_{1}=$ $\rho_{2}$. The critical values of $\phi$ are approximately equal to $10.03,7.37$ and 6.44 at the $1 \%, 5 \%$, and $10 \%$ level, respectively.

The results for the TAR model are reported in Table 6. In the first regime, real exchange rate has no significant effects on commodity prices. The coefficients of oil price on the contrary have the expected signs and are significant. This suggests a positive relationship between oil price and commodity price.

The results show that the effect of real exchange rate becomes significant in the second regime. Thus, a $1 \%$ increase in real exchange rate causes the price of gold, copper and nickel to rise by $0.9 \%, 1.1 \%$, and $2.7 \%$ at an exchange rate above 4.6 . Real interest rate is also positively associated with the price of commodities.

Table 6: estimates of threshold

\begin{tabular}{|l|l|l|l|}
\hline Variables & $\begin{array}{l}\text { Dependent variable } \\
\text { Lgold } \\
(1)\end{array}$ & $\begin{array}{l}\text { Dependent variable } \\
\text { Lcopper } \\
(2)\end{array}$ & $\begin{array}{l}\text { Dependent variable } \\
\text { Lnickel } \\
(3)\end{array}$ \\
\hline Regime 1 & Lrer $<4.613$ & Lrer $<4.614$ & Ler $<4.630$ \\
\hline Lrer & 0.078 & 0.053 & 0.235 \\
& $(0.392)$ & $(0.383)$ & $(0.410)$ \\
\hline
\end{tabular}




\begin{tabular}{|l|l|l|l|}
\hline Loil & $0.189^{* *}$ & $0.572^{* * *}$ & $0.636^{* * *}$ \\
& $(0.080)$ & $(0.081)$ & $(0.100)$ \\
\hline Lrgdp & $1.043^{* * *}$ & $0.703^{* * *}$ & $0.170^{* *}$ \\
& $(0.062)$ & $(0.142)$ & $(0.085)$ \\
\hline Lprod & -0.425 & -0.035 & 0.122 \\
& $(0.471)$ & $(0.209)$ & $(0.617)$ \\
\hline Lrir & -0.012 & 0.023 & 0.033 \\
& $(0.021)$ & $(0.023)$ & $(0.027)$ \\
\hline Cons & -13.511 & -10.461 & $-3.442^{*}$ \\
& $(2.576)$ & $(3.251)$ & $(1.847)$ \\
\hline Regime & Lrer $\geq 4.613$ & Lrer $\geq 4.614$ & Lrer $\geq 4.630$ \\
& & & \\
\hline Lrer & $0.908^{*}$ & $1.136^{* *}$ & $2.759^{*}$ \\
& $(0.539)$ & $(0.587)$ & $(1.671)$ \\
\hline Loil & $0.920^{* * *}$ & $1.587^{* * *}$ & $1.340^{* * *}$ \\
& $(0.131)$ & $(0.157)$ & $(0.196)$ \\
\hline Lrgdp & $0.636^{* * *}$ & 0.174 & -0.188 \\
& $(0.147)$ & $(0.240)$ & $(0.236)$ \\
\hline Lprogold & -0.064 & 0.024 & 0.536 \\
& $(0.545)$ & $(0.213)$ & $(0.543)$ \\
\hline Lrir & $0.047^{* *}$ & $0.189^{* * *}$ & $0.353^{* * *}$ \\
& $(0.022)$ & $(0.020)$ & $(0.036)$ \\
\hline Cons & $-16.781^{* * *}$ & $-13.217^{* * *}$ & $-15.252^{*}$ \\
& $(4.115)$ & $(5.437)$ & $(8.921)$ \\
\hline
\end{tabular}

Note: Lprod refers to the log form of production of gold, copper, and nickel for column 1, 2, and 3, respectively.

The second goal of our econometric analysis is to understand the transmission effect of the real interest rate on the terms of trade. We estimate a 5-dimentional SVAR model.

$\mathrm{A}_{0} \mathrm{y}_{\mathrm{t}}=\mathrm{c}_{0}+\sum_{i=1}^{P} \mathrm{~A}_{\mathrm{i}} \mathrm{y}_{\mathrm{t}-\mathrm{i}}+\epsilon_{\mathrm{t}}$

Where $\mathrm{y}_{\mathrm{t}}$ is vector of endogenous variables including commodity price index, the terms of trade, real exchange rate, real interest rate, and real GDP. We use a larger sample 1992q1-2019q4, because commodity price and consumer inflation index data are available. In addition, we use commodity price index which is composed of fuel and non-fuel price indices which can be a good representation of commodity prices. We first test the stationarity of the data. The log form of the variables are stationary in their level forms except for the real interest rate. Hence we use the first difference of the log of real interest rate. The results are reported in the Appendix section (Table 2 ). We then proceed to the estimation of the restricted SVAR. We adopt this model because of its ability to capture some of the underlying economic theory. We impose the following restrictions on the constraints matrices. We assume that the percentage change in real interest rate is not contemporaneously affected by the percentage changes in all the other variables in the system. However, we assume that real GDP is contemporaneously impacted by all the other variables in the system. Regarding our variable of interest (terms of trade), we assume that it is affected by real 
interest rate, commodity price index and real exchange rate. Real GDP on the other hand has no effect on the terms of trade. The constraints on A and B matrices are expressed as:

$$
\begin{aligned}
& \begin{array}{lllll}
1 & 0 & 0 & 0 & 0
\end{array} \\
& \begin{array}{rlll}
1 & 0 & 0 & 0
\end{array} \\
& \mathrm{~B}=\begin{array}{rrrrr}
. & 0 & 0 & 0 & 0 \\
0 & . & 0 & 0 & 0 \\
0 & 0 & . & 0 & 0 \\
0 & 0 & 0 & . & 0 \\
0 & 0 & 0 & 0 & .
\end{array}
\end{aligned}
$$

We then discuss the mechanism of idiosyncratic real interest rate shocks on the terms of trade. The analysis of inpulse response function provides a strong understanding of the variations in key macroeconomic indicators that can be attributed to a specific shock. The upper left of the figure 2 shows the structural inpulse response function of a shock in the commodity price index on the terms of trade. The identification restriction reveals that a positive shock to commodity price causes an increase in the terms of trade, followed by a decrease in the second and the fourth period. The effects seem to die out after the $5^{\text {th }}$ period. A 1 per cent increase in real exchange rate causes a reduction in the terms of trade by 0.003 per cent. Thus, an increase in the South African Rand worsens the terms of trade.

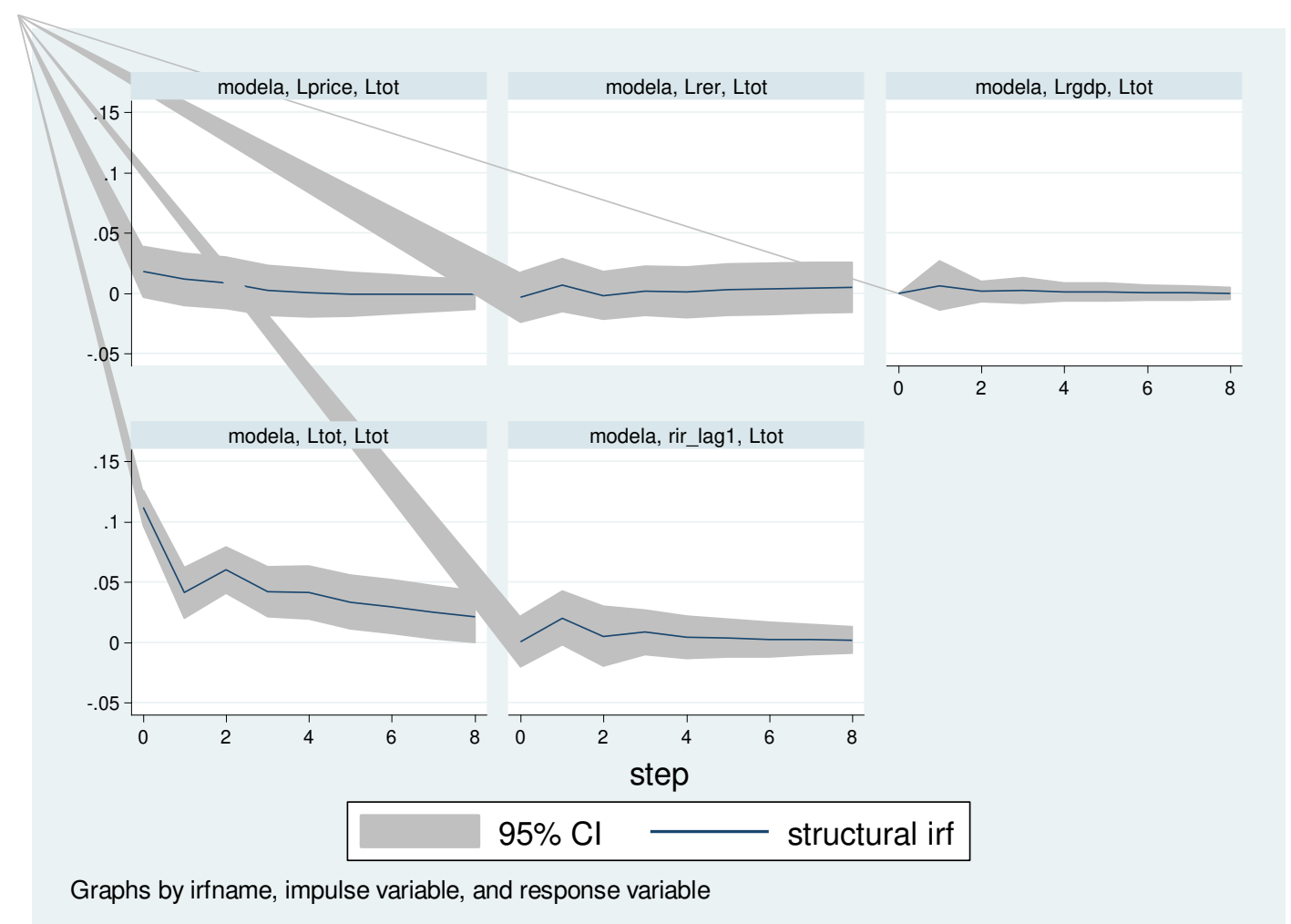

Fig. 2: Distribution of terms of trade responses to an inpulse variable 
The graph shows that external shocks (captured by the change in real interest rate) has an insignificant impact on the terms of trade. Hence commodity prices seem to have a stronger effect on the terms of trade compared to the other variables.

Fig 3 shows the forecast error variance of the terms of trade due to a shock of another variable in the system (see equation 4) or itself. The results confirm our findings that in the short run only commodity price index seem to have a significant effect on the terms of trade. The decomposition of the forecast error variance also reveal that real interest rate can help predict movements in commodity price even though its contribution is not large. This finding is similar to (Anzuini, Lombardi \& Pagano, 2013).

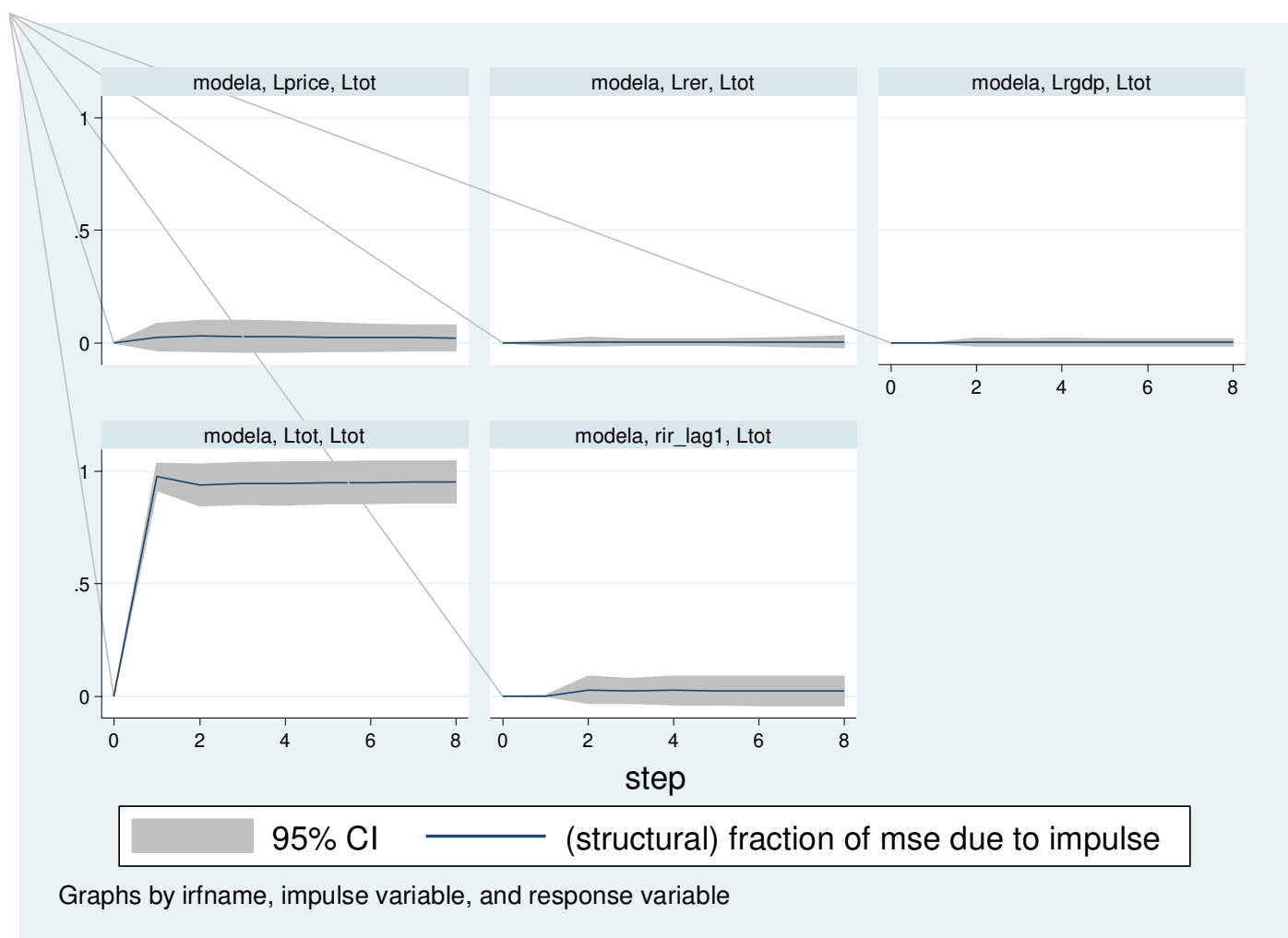

Fig. 3: Share of the variance of the terms of trade explained by a shock in a variable

\section{Conclusion}

Using a linear (ECM) and a threshold autoregressive (TAR) model, the paper examines the impact of real exchange rate on industrial commodity prices. The estimation results provide: (i) evidence of a long run relationship in the model; (ii) the presence of an asymmetric relation between real exchange rate and industrial commodity prices. The depreciation of exchange rate only has a significant influence on gold price. We find that a $1 \%$ increase in real exchange rate leads to $2.18 \%$ rise in the price of gold. 
In all our model specification, we observe a threshold value of 4.6. In both regime, lower and upper, real exchange rate coefficients are positive. However, the coefficients on real exchange rate are only significant in the upper regime. Thus, if real exchange rate above or equal to the threshold is increased by $1 \%$, the price of gold, copper and nickel will increase by $0.9 \%, 1.1 \%$, and $2.7 \%$, respectively.

Further we employ a restricted VAR approach to determine how the terms of trade responds to an external shock. We find that commodity price index is a major determinant of the terms of trade. Changes in the US real interest rate appears to have a moderate effect on commodity prices in a small economy such as South Africa. This has an important implication for policy analysis. It suggests that policy makers in emerging countries should focus on policies that target commodity prices to balance the terms of trade.

\section{References}

Ahumada, H. \& Cornejo, M. (2015). Long-run effects of commodity prices on the real exchange rate: evidence from Argentina. Económica, vol. 61, 3-33

Anzuini, A \& Lombardi, J \& Pagano, P. (2013). The Impact of Monetary Policy Shocks on Commodity Prices, International Journal of Central Banking, International Journal of Central Banking, vol. 9(3), pages 125-150,

Beckmann, J. \& Czudaj, R. (2013). Is there a homogeneous causality pattern between oil prices and currencies of oil importers and exporters? Energy Economics 40, 665-678.

Campos, C. (2020). Are there asymmetric relations between real interest rates and agricultural commodity prices? Testing for threshold effects of US real interest rates and adjusted wheat, corn, and soybean prices. Empirical Economics 59, 371-394

Ding, S \& Zhang, Y. (2020). Cross market predictions for commodity prices, Economic Modelling, Elsevier, vol. 91(C), pages 455-462.

Dornbusch, R. (1976). Expectations and exchange rate dynamics. Journal of Political Economy 84(6):1161-1176

Enders, W. \& Siklos, P. (2001). Cointegration and threshold adjustment. Journal of Business and Economic Statistics 19, 166-176.

Engle, R. \& Granger, C. (1987). Co-integration and error-correction: Representation, estimation, and testing. Econometrica 35: 315-329.

Frankel, J. (2014). Effects of speculation and interest rates in a 'carry trade' model of commodity prices. Journal of International Money and Finance. 42, C:88-112

Frankel, J. (2008). The effect of monetary policy on real commodity prices. In: Campbell JY (ed) Asset prices and monetary policy. NBER books University of Chicago Press, Chicago, pp 291333 
Frankel, J. (1986). Expectations and commodity price dynamics: the overshooting model. American Journal of Agricultural Economics 68:344-348

Frankel, J \& Rose, A. (2010). Determinants of agricultural and mineral commodity prices. HKS Faculty Research Working Paper Series, Harvard University, Cambridge, MA, No. RWP10-038

Gauti, E. \& Summers, L. (2019). Negative interest rate policy and the bank lending channel, VoxEU.org, 24 January

Hamilton, J. (2008). Understanding Crude Oil Prices. National Bureau of Economic Research, Working Paper number 14492.

Lof, M. \& Nyberg, H. (2017). Noncausality and the commodity currency hypothesis. Energy Economics, 65, pp. 424-433.

Mallick, S. \& Sousa, M. (2013). Commodity prices, inflationary pressures, and monetary policy: evidence from BRICS economies. Open Economies. Review, 24 (4), pp. 677-694

Meese, R. \& Rogoff, K. (1983) Empirical exchange rate models of the seventies: do they fit out of sample? Journal of International Economics, 14(1-2):3-24

Nazlioglu, S. \& Soytas, U. (2012). Oil price, agricultural commodity prices, and the dollar: a panel cointegration and causality analysis. Energy Economics 34(4):1098-1104

Obstfeld, M \& Taylor, A. (1997) Nonlinear aspects of goods-market arbitrage and adjustment: Heckscher's commodity points revisited. Journal of the Japanese and International Economies 11:441-479

Pesaran, M.H., Shin, Y. \& Smith, R. (2001). Bounds testing approaches to analysis of level relationships. Applied Economics. 16 (3), 289-326.

Pierdzioch, C., Risse, M. \& Rohloff, S. (2016). Fluctuations of the real exchange rate, real interest rates, and the dynamics of the price of gold in a small open economy, Empirical Economics, Springer, vol. 51(4), pages 1481-1499

Pukthuanthong, K. \& Rol, R. (2011). Gold and the dollar (and the euro, pound, and yen). Journal of Banking and Finance 35:2070-2083

Rossi, B. (2013). Exchange rate predictability. J Economic Literature. 51(4):1063-1119

Salisu, A. \& Mobolaji, H. (2013). Modeling returns and volatility transmission between oil price and US-Nigeria exchange rate. Energy Economics 39, 169-176.

Scrimgeour, D. (2010). Commodity price responses to monetary policy surprises. http://commo ns.colga te.edu/econ_facsc hol/11. Accessed 2 December 2020

Tadesse, G., Algieri, B. Kalkuhl, M. \& Von Braun, J. (2014). Drivers and triggers of international food price spikes and volatility. Food Policy 47:117-128. 


\section{Acknowledgment}

We would like to thank the Trade Research Entity at North West University for providing the facility to carry out this research. A special thanks goes to the editor, the co-editor and the two anonymous reviewers for their comments.

\section{Funding}

The research was funded by the faculty of economics and management sciences at North West University.

\section{Contribution}

The author contributed to the analysis and the writing of the article. The co-author provided guidance throughout the completion of the research project.

\section{Competing interest}

The author declares that he has no competing interests.

\section{Availability of data and materials}

The data will be deposited in the journal. They are submitted along with the manuscript.

\section{Appendix}

Table 1: Variables definition and sample mean

\begin{tabular}{|l|l|l|}
\hline & Mean & Definition \\
\hline Gold & 4.38 & Price of gold adjusted for inflation \\
\hline Copper & 25.42 & Price of copper adjusted for inflation \\
\hline Nickel & 74.75 & Price of nickel adjusted for inflation \\
\hline rer & 99.68 & Real effective exchange rate \\
\hline gdp & 2123988 & Real gross domestic product \\
\hline progold & 101.05 & Production of gold \\
\hline Procopper & 119.84 & Production of copper \\
\hline Pronickel & 75.54 & Production of Nickel \\
\hline
\end{tabular}




\begin{tabular}{|l|l|l|}
\hline Rir & 4.88 & US real interest rate \\
\hline Tot & 133.88 & $\begin{array}{l}\text { Exports value of all commodities/ imports value of } \\
\text { all commodities }\end{array}$ \\
\hline Price & 162.11 & $\begin{array}{l}\text { All Commodity Price Index, 2016 = 100, includes } \\
\text { both Fuel and Non-Fuel Price Indices }\end{array}$ \\
\hline
\end{tabular}

Table 2: system of equation cointegration test

\begin{tabular}{|c|c|c|c|c|}
\hline \multirow[t]{2}{*}{ Variables } & \multicolumn{2}{|c|}{ Model specification } & \multirow[t]{2}{*}{ T-statistics } & \multirow{2}{*}{$\begin{array}{l}\text { Unit root test status } \\
\text { (5\% level) }\end{array}$} \\
\hline & $\begin{array}{l}\text { Without } \\
\text { trend }\end{array}$ & With trend & & \\
\hline \multicolumn{5}{|l|}{ ADF } \\
\hline \multicolumn{5}{|c|}{ Commodities } \\
\hline $\begin{array}{l}\text { Commodity } \\
\text { price index }\end{array}$ & $\begin{array}{l}-0.295^{* * * *} \\
(0.068)\end{array}$ & $\begin{array}{l}-0.30 * * * \\
(0.069)\end{array}$ & -3.940 & No \\
\hline \multicolumn{5}{|c|}{ Macroeconomic variables } \\
\hline Lrer & $\begin{array}{l}-0.110^{* * * *} \\
(0.040)\end{array}$ & $\begin{array}{l}-0.11 * * * \\
(0.040)\end{array}$ & -2.71 & No \\
\hline Lrgdp & $\begin{array}{l}-0.006^{* * * *} \\
(0.001)\end{array}$ & $\begin{array}{l}0.01 \\
(0.015)\end{array}$ & -4.231 & No \\
\hline Itot & $\begin{array}{l}-0.08^{*} \\
(0.042)\end{array}$ & $\begin{array}{l}-0.19^{* * *} \\
(0.075)\end{array}$ & -1.891 & No \\
\hline d.Lrir & $\begin{array}{l}-0.72 * * * \\
(0.092)\end{array}$ & $\begin{array}{l}-0.73^{* * *} \\
(0.093)\end{array}$ & -7.88 & No \\
\hline
\end{tabular}

Note: Critical values for the ADF with a trend are: -4.036 and -3.449 at the $1 \%$ and $5 \%$ levels, respectively. Critical values for the ADF without a trend are: -2.361 and -1.659 at the $1 \%$ and $5 \%$ levels, respectively. we report the results of the T-statistics without trend in levels based on the visual data. All the series are stationary using the Akaike information criteria.

Table 3: Cholesky decomposition of the structural VAR

\begin{tabular}{|l|l|l|l|l|l|}
\hline Variables & Lrir & lprice & Lrer & Ltot & lrgdp \\
\hline Lrir & 0.34005 & 0 & 0 & 0 & 0 \\
\hline Lprice & 0.00351 & 0.05847 & 0 & 0 & 0 \\
\hline Lrer & 0.01348 & -0.00093 & 0.057678 & 0 & 0 \\
\hline Ltot & 0.00067 & 0.017968 & -0.00310 & 0.11141 & 0 \\
\hline Lrgdp & -0.00107 & -0.00073 & -0.00058 & -0.00285 & 0.01007 \\
\hline
\end{tabular}


Figures
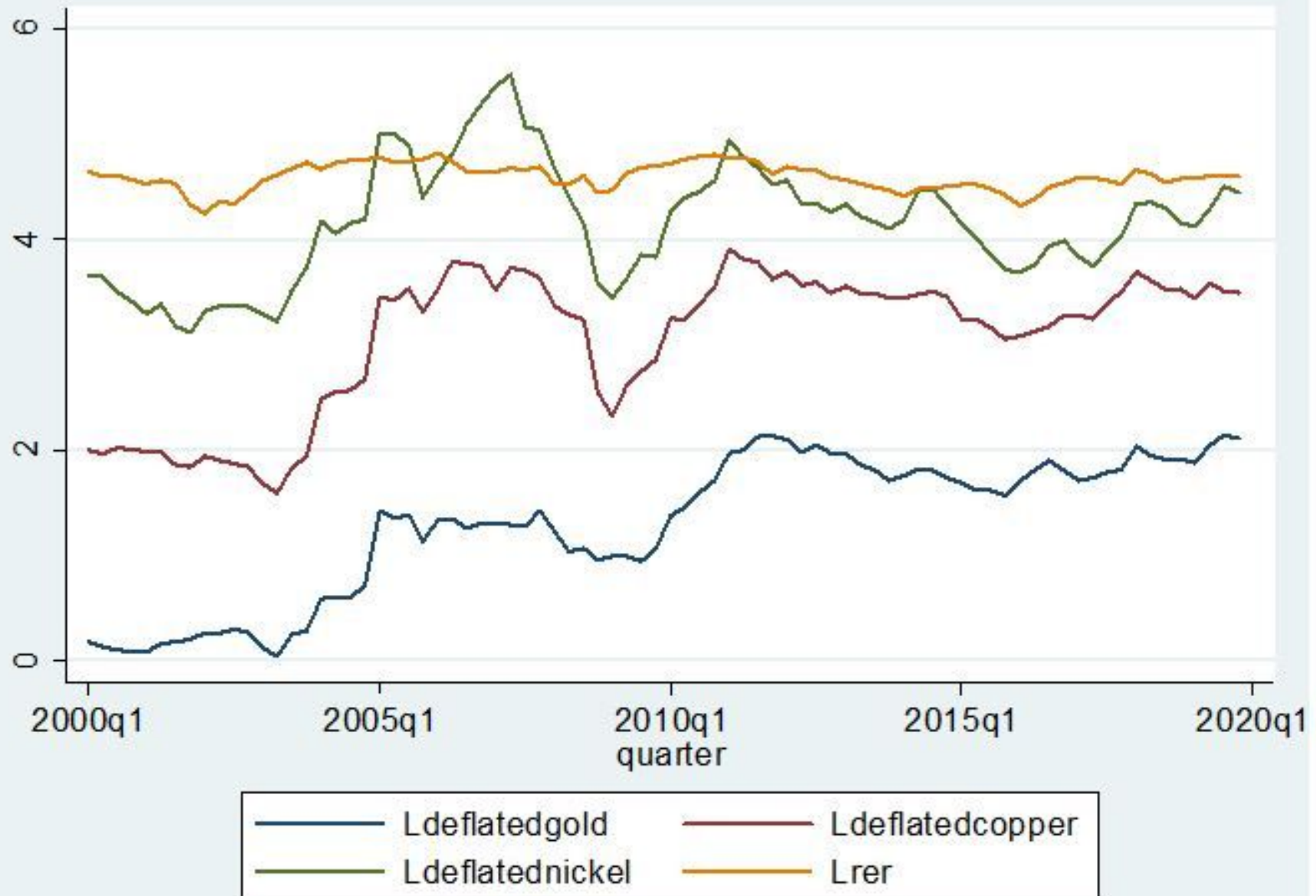

Figure 1

Deflated industrial commodity prices vs real exchange rate from $2000 q 1$ to $2019 q 4$. Source: Author's estimation 

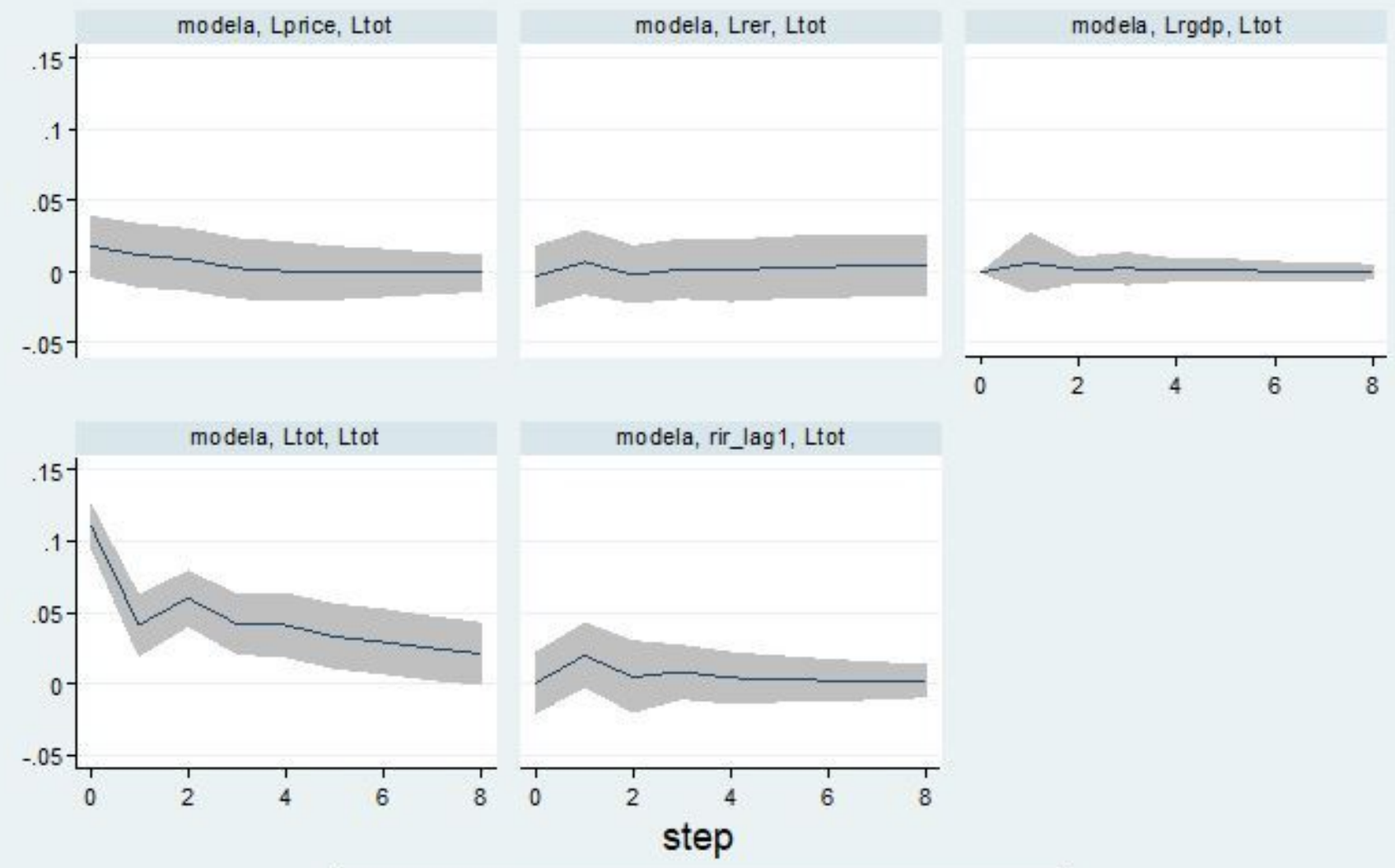

\section{$95 \% \mathrm{Cl}$ structural irf}

Graphs by irfname, impulse variable, and response variable

Figure 2

Distribution of terms of trade responses to an inpulse variable 

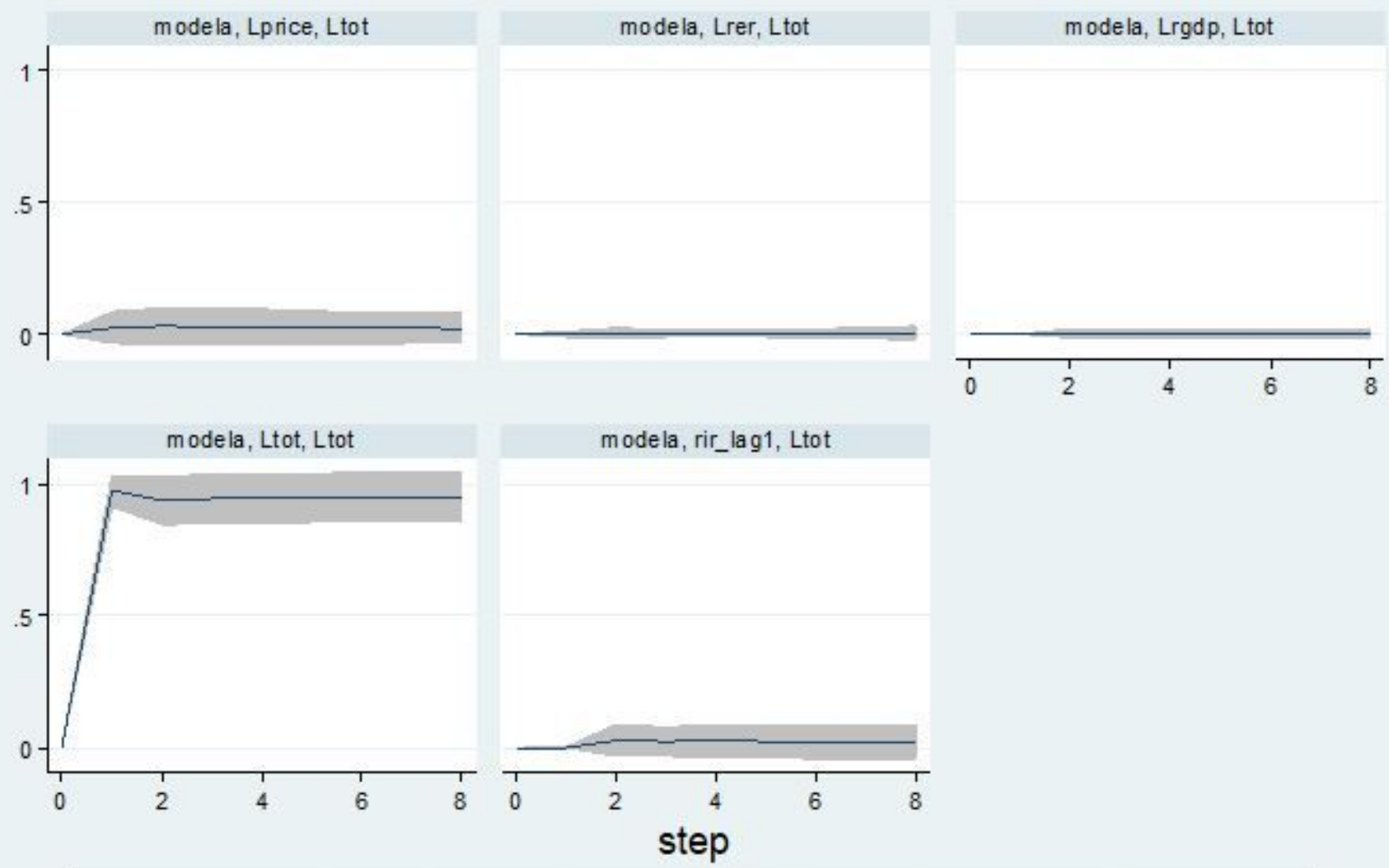

\section{$95 \% \mathrm{Cl}$ (structural) fraction of mse due to impulse}

Graphs by irfname, impulse variable, and response variable

\section{Figure 3}

Share of the variance of the terms of trade explained by a shock in a variable

\section{Supplementary Files}

This is a list of supplementary files associated with this preprint. Click to download.

- Appendix.docx 